\title{
Assessment of Large Seed Banks Requirement for Drought Risk Management in South Asia
}

\author{
Arun Khatri-Chhetri * (D) and Pramod K. Aggarwal * \\ CGIAR Research Program on Climate Change, Agriculture and Food Security (CCAFS), \\ International Maize and Wheat Improvement Center (CIMMYT), New Delhi 110012, India \\ * Correspondence: a.khatri-chhetri@cgiar.org (A.K.-C.); p.k.aggarwal@cgiar.org (P.K.A.); Tel.: +91-11-2584-2940
}

Received: 30 August 2017; Accepted: 19 October 2017; Published: 1 November 2017

\begin{abstract}
Agriculture in South Asia is largely dependent on rainfall, where about two-thirds of the cultivable lands lack irrigation facilities. In recent years, increasing frequency and severity of droughts have had a severe impact on rainfed agriculture and livelihood of millions of farmers in the region. There are numerous drought adaptation and mitigation options available for rainfed agriculture. A seed bank is one of those options that can play an important role in minimizing the effect of droughts on crop production. This paper assesses the need for seed banks in rainfed/partially irrigated areas of South Asia for the purpose of drought risk management. The need for additional seeds of the main crops or suitable alternative crops for re-sowing/planting after drought-induced losses of the main crop was assessed by using long-term gridded rainfall data and crop information. Results show that very limited rainfed areas in South Asia require additional seeds of main or alternative crops for drought risk management once in five to seven years' drought return period. About 90 percent of such areas in South Asia may require additional seeds for drought risk management once in 10 years or more. The timing and severity of droughts during cropping season and cost/benefits of seed bank maintenance play a major role in choosing additional seeds for the main crops and/or alternate crops for maintenance in the large seed banks. This study shows that, despite the large investment requirement, maintenance of large seed banks for drought risks management is economically viable for the limited areas in South Asia.
\end{abstract}

Keywords: seed bank; drought; crop failure; cropping season; South Asia; drought return period

\section{Introduction}

Erratic rains and droughts are among the major constraints in agricultural production in South Asia, where more than 700 million people are directly dependent on agriculture for their livelihoods [1,2]. The majority of agricultural lands in the South Asian subcontinent are rainfed/partially irrigated and frequently experience a shortage of water during the cropping season. The frequency and severity of droughts in the subcontinent have drastically increased in the last few decades [3,4]. Afghanistan, India, Pakistan, and Sri Lanka have reported droughts at least once every three years, while Bangladesh, Bhutan, and Nepal have also suffered from frequent droughts. The major drought-prone states in India are Rajasthan, Gujrat, Maharashtra, Karnataka, Andhra Pradesh, and Odisha [5,6]. Large parts of southern Afghanistan, southern parts of Pakistan (Baluchistan and Sindh States), north-western Bangladesh (Rajshahi, Khushtia, Jessore, and Khulna Divisions) and north-western Nepal also experience frequent droughts [7-9]. Between 1900 and 2015, droughts affected 1.06 billion people and resulted in losses amounting to approximately US \$ 5.4 billion [4].

Climate change is projected to further aggravate drought events globally, including rainfed regions in South Asia where a majority of the farmers are dependent on rainfall for agricultural operations. Many reports indicate that climate variability would indeed increase with warmer climates and in turn 
intensify the frequency of droughts in many rainfed areas [3]. A number of studies have also reported a tendency for intra and inter-seasonal rainfall variability to increase over South Asia under climate change $[10,11]$. Therefore, the agriculture sector in South Asia needs to be prepared to face increased climate variability and more frequent and severe droughts.

Drought events in South Asian countries are typically responded to only after disasters, and little attention is given to the preparedness that could reduce drought impacts in agriculture and lessen the financial burden [12]. National climate change adaptation and mitigation policies in South Asian countries focus on the development of drought monitoring and early warning systems, promotion of irrigation development and rainwater management, and enable farmers to adopt proper crop management strategies [13-15]. Many technologies and practices such as water harvesting for supplemental irrigation, conservation agricultural practices, and cultivation of drought tolerant varieties that minimise the damage to crops from the long dry spells during the cropping season [16,17]. Activities such as the development of irrigation systems, improved irrigation technologies/practices, alternative land use plans, development of seed banks, and weather information based value added agro-advisory systems can increase the level of readiness or improve communities' capacity to adapt to and cope with drought events and other climatic risks [18-20]. Many countries in South Asia are also exploring the potential of mitigating drought impacts on livelihood and food security through agriculture insurance programmes.

The onset of rainfall and time of crop establishment are strongly correlated in rainfed and partially irrigated areas. The prevalence of a long drought just after crop sowing can lead to crop failure. In many locations, farmers can re-establish the main crop with short-duration varieties or sow alternative crops with the revival of rainfall. In such cases, farmers require additional seeds of the main crop or alternative crops for re-sowing/planting when rainfall recurs. But farmers generally do not store additional seeds of main or alternative crops for re-sowing after crop failure due to in-season droughts. The establishment of large seed banks in drought prone areas can be an alternative to supply sufficient additional seeds to the farmers.

All countries in South Asia are planning to establish large seed banks at regional and sub-regional levels to attain seed security in agriculture through storage and exchange of seeds across the region [21-23]. It is therefore important to identify areas in the region which are prone to crop failure due to the prevalence of droughts. It is also necessary to estimate the return period of severe drought, identify suitable varieties of main crop and alternative crops for re-sowing, quantity of seeds required to plant after failure of the main crop, and cost of maintaining seed banks in the drought-prone areas. Despite the role of seed banks in drought risk management in agriculture, there are no systematic studies conducted to identify the scope for establishing large seed banks for the government or the private sector in the South Asian countries.

This paper presents a scientific assessment of the role that large seed banks can play in drought risk management during a particular period of cropping season in the rainfed and partially irrigated agricultural areas. This paper assesses (i) the probability of severe droughts during crop sowing time and its return period; (ii) the potential of re-sowing the main crops or sowing of alternative crops after severe droughts; (iii) the amount and type of seeds (crop and variety) required to be maintained in the seed banks; and (iv) the cost of maintaining seeds in the seed banks to be supplied during the time of drought induced crop failure. This information is particularly important for planning in-season drought risks management through the revival of crop production and in maintaining food supply. The quantity of additional seeds requirement can be quite large, often in several thousands of tonnes depending on the location, areas, and severity of drought. This study provides useful information to the policy makers to make investment decisions regarding storing additional seeds in the existing seed banks or new seeds banks (which governments plan to establish) in the locations where droughts cause crop failure at the early growing stage. 


\section{Methodology}

\subsection{Identification of Rainfed/partially Irrigated Areas}

This study was conducted for rainfed/partially irrigated croplands in seven countries in South Asia: Afghanistan, Bangladesh, Bhutan, India, Nepal, Pakistan, and Sri Lanka. The flow chart in Figure 1 presents a method of identification of study grids using various spatial datasets. The South Asian region was divided into $0.50 \times 0.5^{\circ}$ grids and the valid study grids which have rainfed/partially irrigated agricultural land were identified. From the application of GIS tool, all grids with Cropland and Cropland/Natural Vegetation Mosaic were retained and other land use classes were masked out [24]. The FAO Global Map of Irrigation Areas (GMIA) version 4.0.1 was used to develop an irrigated mask [25]. All grids with less than 50 percent of the area under irrigation were considered as rainfed/partially irrigated. Daily rainfall data for each grid spans a period of 47 years (1961-2007) precipitation data aggregated over 52 standard meteorological weeks (SMW) for each year. The time series of weekly gridded rainfall dataset developed by APHRODITE (Asian Precipitation-Highly-Resolved Observational Data Integration Towards Evaluation) was used to identify valid crop sowing period in each grid and a Standardized Precipitation Index (SPI).

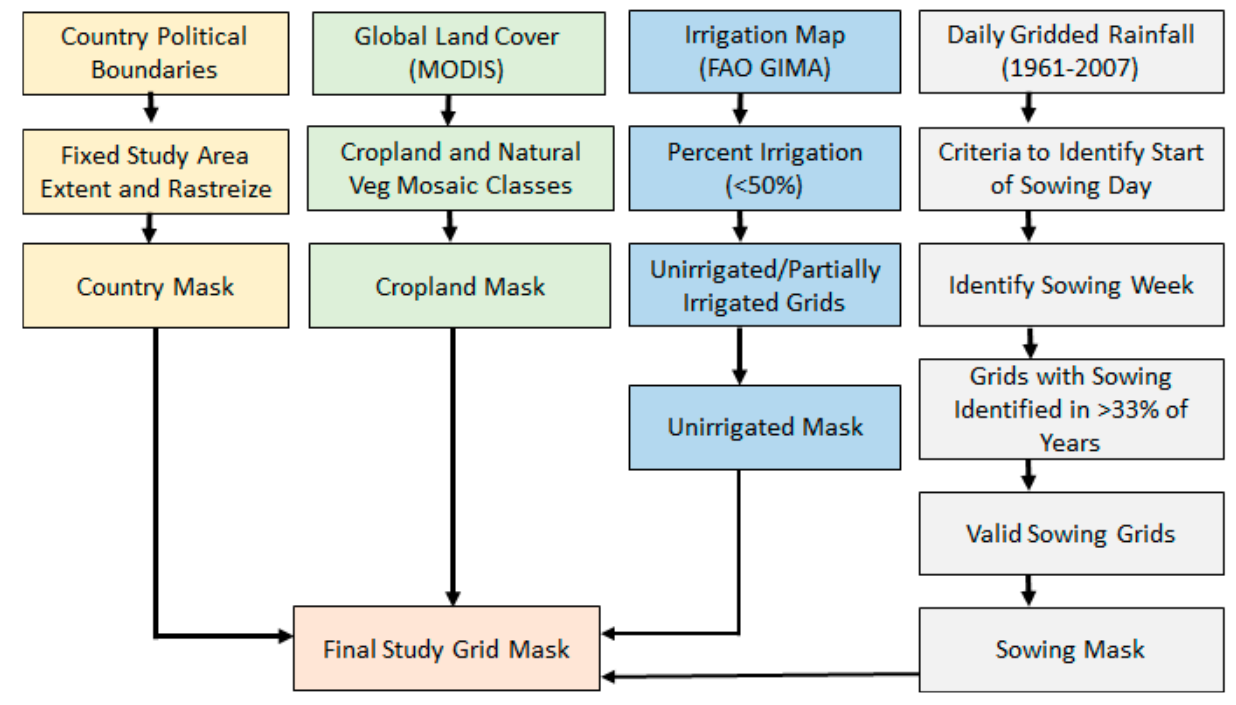

Figure 1. Identification of rainfed/partially irrigated areas including valid sowing days using spatial datasets.

Figure 2 presents mapping of SPI values across the South Asian region. Many locations in central and eastern India, western Nepal and Bangladesh, and some places in Afghanistan had moderate to extremely dry condition in the last 47 years. These results are consistent with mappings of drought patterns in the region $[26,27]$.

This study considers that the main crop is sown in rainfed and partially irrigated areas on time with the onset of rainfall in the beginning of monsoon. Using daily gridded rainfall dataset, the following criteria were used to identify crop sowing periods in each grid. In South Asia, the monsoon season crops are sown between 14 June and 30 July each year. This information is available in crop calendars of major crops published by the Ministry of Agriculture in each South Asian country. Based on the existing literature (e.g., [28,29]) and expert consultations, we considered that crop sowing commences when the following conditions are first met: (a) at least $25 \mathrm{~mm}$ of cumulative rainfall is received for seven continuous days and (b) there are at least three rainy days (rainfall $>2.0 \mathrm{~mm}$ ) in those seven days. If both conditions were met, then the first day of the continuous seven-day rain period is the day sowing begins, and the corresponding week was considered the sowing week. 


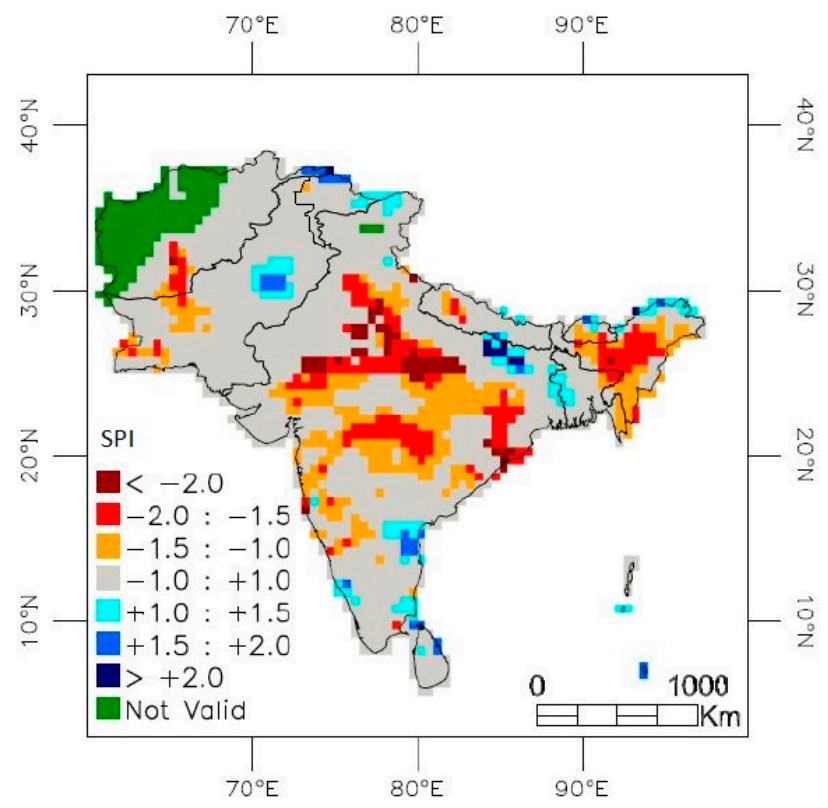

Figure 2. Map of Standardized Precipitation Index (SPI) indicting the probability of occurrence of droughts.

In case any of the above conditions were not met, then the seven-day period was advanced by one day and searched again as per the criteria mentioned above, till a valid sowing day was obtained or till it reached $30 \mathrm{July}$. In case no sowing day was found, the grid was assigned a value zero to mark it as "invalid sowing". Using the computed sowing period data for 47 years (1961-2007), a median sowing week was calculated for all the grids with valid sowing period (Figure 3). The valid sowing periods were synchronised with Standard Meteorological Weeks (SMWs) to correlate sowing time with the crop calendar for each study grid. The mask of valid study grids in South Asia was generated by overlaying masks of study area, the croplands land uses, rainfed/partially irrigated areas, and valid sowing periods. All further analysis of the datasets was carried out only for these valid grids.

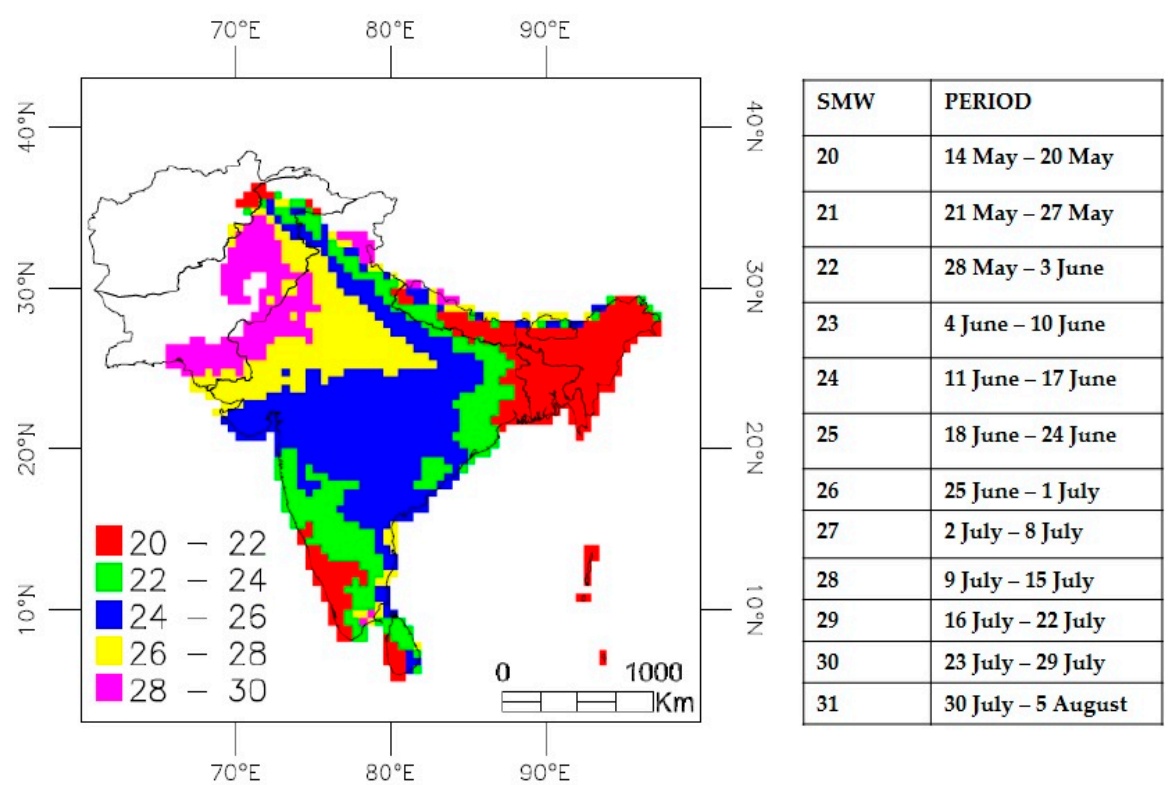

Figure 3. The median start of the sowing week for the valid sowing grids of the study region including the sowing period corresponding to different standard meteorological weeks (SMWs). 


\subsection{Identification of Additional Seed Requirement Areas}

After identification of the valid sowing period for study grids, we identified the locations that may have requirements for additional seeds of the main crops or seeds of alternative crops. The weekly rainfall information was used to compute the rainfall anomaly of Standardized Precipitation Index (SPI) to identify meteorological drought conditions and normal rainfall conditions for each grid in every monsoon crop season over 47 years. The SPI is a dimensionless index with negative values indicating drought and positive values that of wet conditions. A drought event (meteorological drought) occurs any time when the SPI is continuously negative and reaches an intensity of -1.0 or less [30].

Four scenarios mentioned in Figure 4 were postulated for computation of normal rainfall conditions and meteorological drought at different stages of crop season (Table 1). These four scenarios were developed based on crop water requirement and crop's survival capacity under water deficit conditions which are discussed in many studies (e.g., [31]). We have also consulted with many crop specific experts to understand crop water requirement and impact of drought after sowing in the study areas. In the rainfed/partially irrigated areas, three or more weeks of continuous drought after crop sowing causes crop failure. All scenarios correspond to additional seed requirement of either short-duration variety of the main crop or alternative short duration crops suitable for specific location to re-sowing/planting on the revival of rainfall.

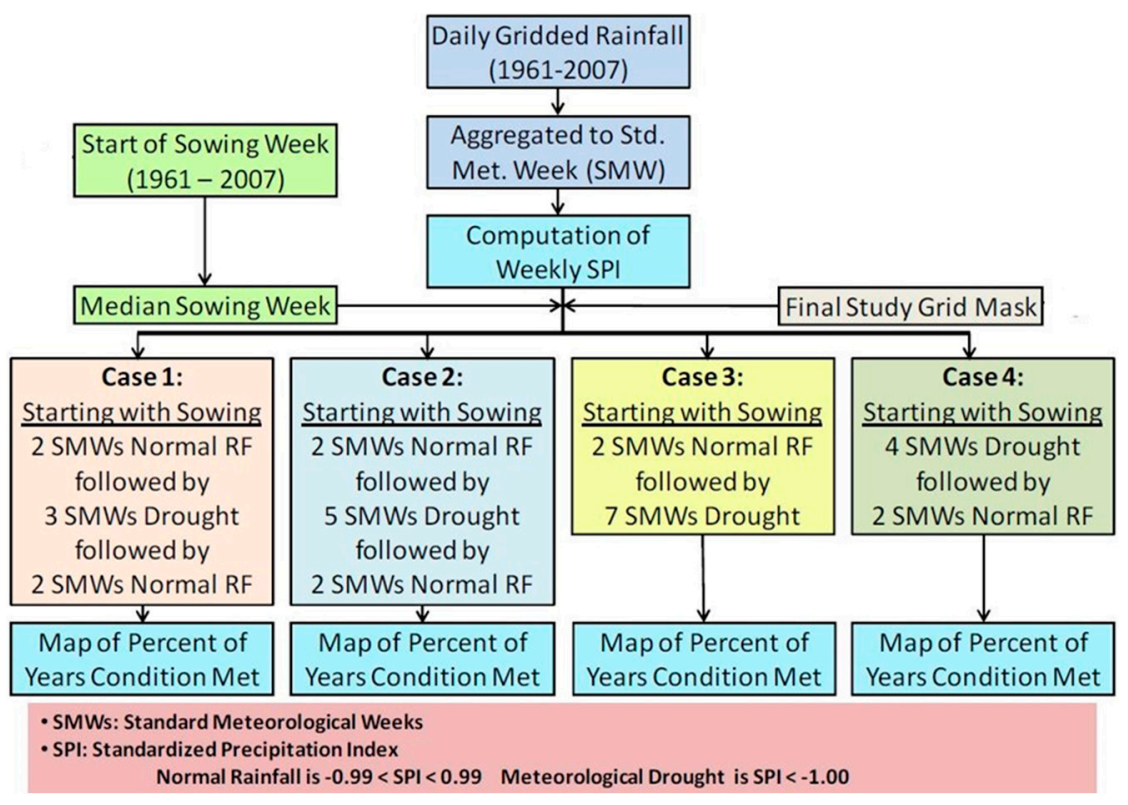

Figure 4. Steps to identify locations where additional seeds are required for re-sowing after crop failure due to prolonged drought conditions.

Each of the four scenarios in Table 1 was analysed and mapped as "percent of years scenario was true" based on the historical rainfall data. These probabilities classified into five categories: (a) $0-5 \%$, (b) $5-10 \%$, (c) $10-5 \%$, (d) $15-20 \%$, and (e) $20-25 \%$. The reciprocal of "percent of years scenario was true" was used to calculate the return period for that scenario. The return period is the inverse of the probability that the drought event exceeds in any one year or more accurately the inverse of the expected number of drought occurrences in a year. Thus, the return period of more than 20 years, 20-10 years, $10-7$ years, $7-5$ years, and $5-4$ years were estimated correspond to $0-5 \%, 5-10 \%, 10-15 \%$, $15-20 \%$, and $20-25 \%$, respectively. This return period for all study areas was assessed to know the areas for additional seed requirement and the time interval for each scenario. 
Table 1. Different scenarios based on rainfall and sowing period.

\begin{tabular}{|c|c|c|}
\hline Scenario & Description & Additional Seed Requirement \\
\hline $\begin{array}{l}\text { 1. Normal rainfall during } \\
2 \text { sowing weeks followed by } \\
3 \text { weeks drought and then } \\
\text { revival of rainfall in subsequent } \\
2 \text { weeks (N2-D3-N2) }\end{array}$ & $\begin{array}{l}\text { Timely sowing of the main crops due to } \\
\text { sufficient rainfall during two weeks of the } \\
\text { sowing period leading to proper } \\
\text { germination, crops then experience severe } \\
\text { moisture deficit during early growth for } \\
\text { a short period of three weeks and then } \\
\text { normal rainfall resumes }\end{array}$ & $\begin{array}{l}\text { There may be seed requirement for } \\
\text { re-sowing of the main crop but } \\
\text { with short duration varieties }\end{array}$ \\
\hline $\begin{array}{l}\text { 2. Normal rainfall during } \\
2 \text { sowing weeks followed by } \\
5 \text { weeks of drought and then } \\
\text { revival of rainfall in subsequent } \\
2 \text { weeks (N2-D5-N2) }\end{array}$ & $\begin{array}{l}\text { Timely sowing of the main crops due to } \\
\text { sufficient rainfall during two weeks of } \\
\text { sowing period leading to proper } \\
\text { germination, crops then experience severe } \\
\text { moisture deficit during early growth for } \\
\text { a longer period of five weeks and then } \\
\text { normal rainfall resumes }\end{array}$ & $\begin{array}{l}\text { There may be a requirement of } \\
\text { additional seeds for sowing of } \\
\text { alternate short duration crops. } \\
\text { There is no possibility of } \\
\text { re-sowing of the main crop with } \\
\text { short duration varieties due to the } \\
\text { prolonged period of drought }\end{array}$ \\
\hline $\begin{array}{l}\text { 3. Normal rainfall during } \\
2 \text { sowing weeks followed by } \\
7 \text { weeks of drought (N2-D7) }\end{array}$ & $\begin{array}{l}\text { Timely sowing of the main crops due to } \\
\text { sufficient rainfall during two weeks of } \\
\text { sowing period leading to proper } \\
\text { germination but subsequently crops } \\
\text { experience severe moisture deficit during } \\
\text { a prolonged period of seven weeks leading } \\
\text { to a complete destruction of the main crop }\end{array}$ & $\begin{array}{l}\text { There may be no requirement of } \\
\text { additional seeds of the main crop } \\
\text { as well as alternative crops. } \\
\text { Establishment of the main crop or } \\
\text { alternative crops may not be } \\
\text { possible after long drought period }\end{array}$ \\
\hline $\begin{array}{l}\text { 4. Drought during } 4 \text { weeks of } \\
\text { sowing period followed by } \\
\text { normal rainfall (D4-N2) }\end{array}$ & $\begin{array}{l}\text { Normal sowing window of two weeks as } \\
\text { well as for the subsequent period of two } \\
\text { more weeks such that sowing of the main } \\
\text { crops is not possible. After the prolonged } \\
\text { drought period, the normal rainfall resumes } \\
\text { in subsequent two weeks }\end{array}$ & $\begin{array}{l}\text { Sowing of the main crops is not } \\
\text { possible and there may be } \\
\text { requirement of additional seeds } \\
\text { only for sowing of alternate short } \\
\text { duration crops. }\end{array}$ \\
\hline
\end{tabular}

\subsection{Identification of Crops Combinations}

This study identified the area-specific crop combinations depending on agronomic and environmental conditions of the study areas. A crop combination of the main crop sown in the area under normal rainfall conditions and its alternative crop that may be sown under the four specific scenarios were identified for areas needing seed banks. In all the areas where additional seeds were required, data on the soil type, agro-ecological conditions, major crops/varieties grown in the area, and possible alternative crops/varieties suitable for that area were collated from the agricultural statistics of each location. The identification of alternative crops or short duration varieties of the main crops under each scenario was done based on (a) expert judgment considering the climatic and environmental factors and (b) the recommended list of crops in the District Crop Contingency Plans published by the governments.

\subsection{Economic Analysis of Seed Bank}

The cost of managing a seed bank was estimated only for areas that require additional seeds in India. For the additional seed requirement areas, net crop sown areas were estimated based on agricultural statistics of India. The seed rate, germination percentage of seed with time, the cost of seed for each crop, and operational cost for storing seeds in seed banks were collected from SeedNet portal of the Ministry of Agriculture and published research reports and papers. For this study, the seed rate and seed cost per unit quantity were considered to be uniform across the country and the rate of seed pilferage per year was taken as 5 percent of the seeds stored. The seed rate was compensated for 90 percent germination to arrive at the crop-wise seed requirement for each location. For alternative crops, the total area under each crop was multiplied with the seed rate, accounted for 120 percent enhanced application rate due to late sowing and then compensated for 90 percent germination. The total cost of additional seeds for re-sowing/planning in a particular location was estimated by 
multiplying the total amount of individual crop's seed with the corresponding price. This study estimates costs of storing additional seeds in current price (study year 2014) using a 5\% discount rate.

The net returns from crop cultivation in normal and drought years for the study locations were estimated by using crop yields and costs data available on the website of Department of Agriculture, India. The government's data on the cost of cultivation for major crops across the country provides detailed input and output information. The long term net returns from crop cultivation $(5,10$, and 15 years) were estimated by using a $5 \%$ discount rate.

\section{Results and Discussion}

\subsection{Drought After Sowing of the Main Crop}

This section presents the results based on the assessment of each scenario which are discussed in Table 1. Scenarios one to three represent the prevalence of short (three weeks), medium (five weeks), and severe drought (seven weeks) conditions after sowing of the main crops. Figure 5 presents a percent of years the scenario one is true where normal rainfall occurs during two weeks of crop sowing followed by three weeks of drought and then revival of rainfall in the subsequent two weeks. The results show that continuous three weeks drought after sowing of the main crops may exist in more than 50 percent of the study areas once in 20-10 years (average 13 years). This scenario may exist only in less than one percent of study areas once in 7-5 years. The area with a 7-5 year drought return period in scenario one are located in Rajasthan (Udaipur and Bhilwara districts), Bihar (Begusarai and Munger districts), and Andhra Pradesh (Kurnool district) of India. In other countries, continuous three-week drought after sowing of the main crops does not frequently occur.



Figure 5. Percentage of years with scenario one is true in the study area.

Re-sowing of the main crop or sowing of alternative crops is possible under this scenario. Farmers can get seeds from the seed banks or other sources to establish the crops in their fields. However, this scenario does not occur frequently across large areas, and therefore, maintenance of additional seeds in seed banks at a large scale for such a long period of time (13 years) may not be a feasible solution for drought management. Drought may last just three weeks after the onset of normal rainfall during the crop sowing week. Water conservation technologies and the development of rainwater harvesting systems for supplemental irrigations can tackle three weeks of drought conditions and prevent crop failure before the revival of normal rainfall [32,33]. Promotion of drought resistant 
crop varieties can be another option for coping with this short duration drought $[34,35]$. However, this scenario still exists in few locations (less than one percent study area), where local seed banks can play a critical role in adapting to drought by re-sowing of the main crop or sowing of alternative crops after revival of rainfall.

Figure 6 presents the percentage of years the scenario two where normal rainfall occurs during the two weeks of crop sowing followed by five weeks of drought and revival of normal rainfall. The results show that continuous three weeks drought after sowing of the main crops may exist in more than 50 percent of the study areas once in 20-10 years (average 13 years). Less than half percent of the study areas showed this drought condition once every 5-7 years. These grids are located in Bangladesh and Andhra Pradesh (Anantapur district) of India. None of the study areas have less than a five-year return period of this drought condition.

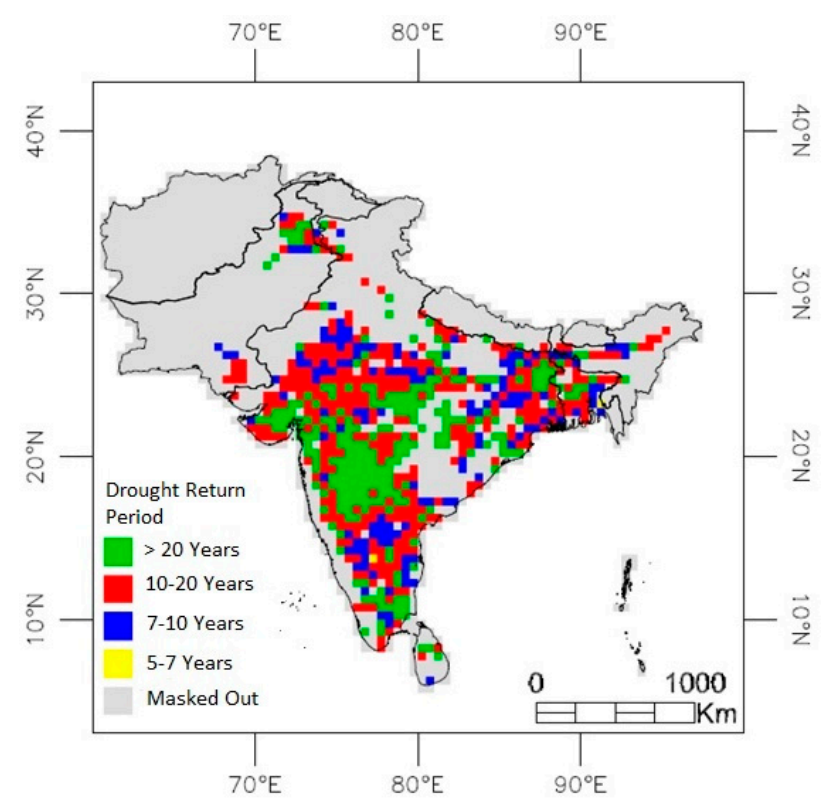

Figure 6. Percentage of years with scenario two is true in the study area.

Again, this scenario may not occur frequently. However, the crop can fail completely with five weeks of severe drought. This condition does not allow farmers to re-sow the main crop using short duration varieties. Instead, farmers may adopt a combination of technologies and practices to use rainfall efficiently during the sowing period and use low water requirement/drought tolerant varieties [32-35]. In these locations, the loss of revenue from poor crop yields owing to drought conditions can be compensated through crop insurance programmes or similar kinds of programmes.

Figure 7 presents the percentage of years where scenario three is true: where normal rainfall occurs during two weeks of crop sowing followed by seven weeks of drought. Results show that continuous seven weeks drought after sowing of the main crops may exist in more than 50 percent of the study areas once in 7-10 years (average 9 years). The drought condition under this scenario would be severe and farmers may observe the complete failure of their crop after sowing. The sowing window for main or alternative cover is completed after seven weeks of drought. In this situation, re-sowing of the main crop or sowing of alternative short duration crop is not possible after the long drought period. Therefore, there is no need to maintain any additional seeds of the main or alternative crops in such types of drought-prone locations. 


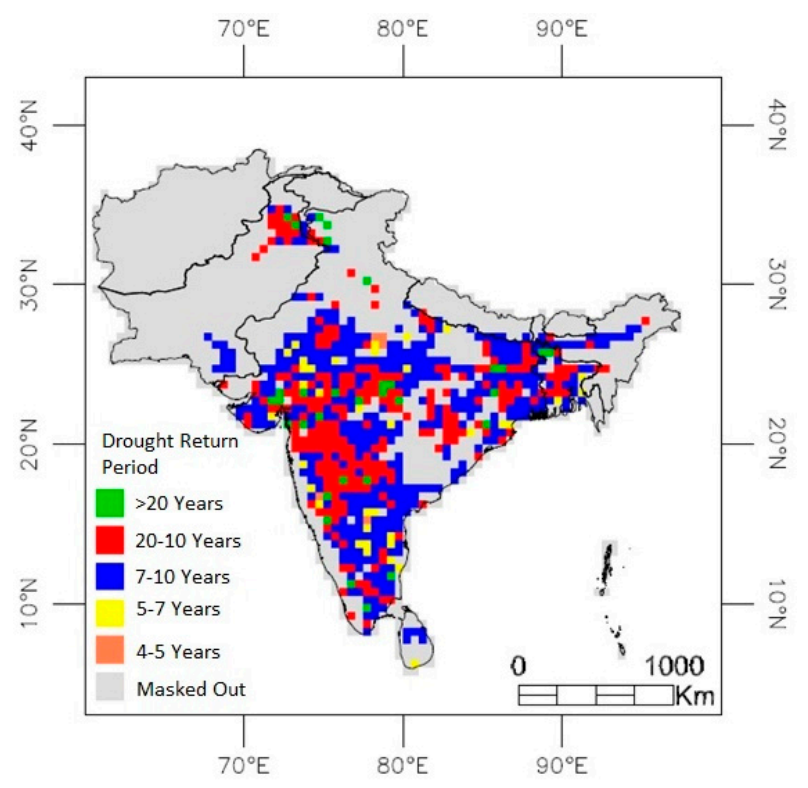

Figure 7. Percentage of years when scenario three is true in the study area.

In recent years, the frequency of this kind of drought condition has significantly increased in the Indian subcontinent [36,37]. These droughts have caused huge losses in agricultural production with increasing financial and social burdens to the communities living in these drought prone areas. Under this scenario, farmers may not be able to re-establish the crop in the same cropping season, and water conservation technologies/practices including rainwater harvesting may not be very effective. Insurance against drought and social safety net programs could help the affected farmers to cope with crop failure. In recent years, rainfall index-based crop insurance has been presented as an effective tool that can help farmers tide over yield loss or crop failure due to a deficit rainfall [38,39]. In many parts of India and Nepal, agriculture insurance schemes for drought induced crop failure are in place to support distressed farmers.

\subsection{Drought During Crop Sowing Periods}

The South Asian summer monsoon, which is very critical to agriculture in the region, has been weakened and delayed in recent years [11,40]. This study assessed the probability of drought during four weeks of crop sowing period followed by normal rainfall (scenario four) and its return period in each study grid. Figure 8 presents the percentage of years where scenario four is true. Results show that this scenario may exist in 50 percent of grids once in nine years. Similarly, scenario four may exist only in 6 percent of study grids once every five to seven years. A total of 43 grids were identified with five to seven-year return period of scenario four. Of these 43 grids, 32 lie in India, 3 in Bangladesh, 4 in Pakistan, and 4 in Sri Lanka. In India, most of these areas are located in the states of Maharashtra, Madhya Pradesh, Rajasthan, Gujarat, Telangana, Bihar, and West Bengal. The probability of occurrence of pre-season drought in these states is also very high (6). Drought during crop sowing periods can also occur in Sylhet and Chittagong divisions in Bangladesh, Sindh and Khyber Pakhtunkhwa provinces of Pakistan, and Anuradhapura, Polonnaruwa, and Matale districts in central Sri Lanka. None of the valid grids of rainfed/partially irrigated areas in Afghanistan, Bhutan, and Nepal showed an incidence of this scenario once in five to seven years.

Under scenario four, the re-sowing of the main crops would not be possible. These locations may require additional seeds of alternative short duration crops. Maintenance of seeds of alternative crops in seed banks can help farmers to re-sow crops on the revival of rainfall. 


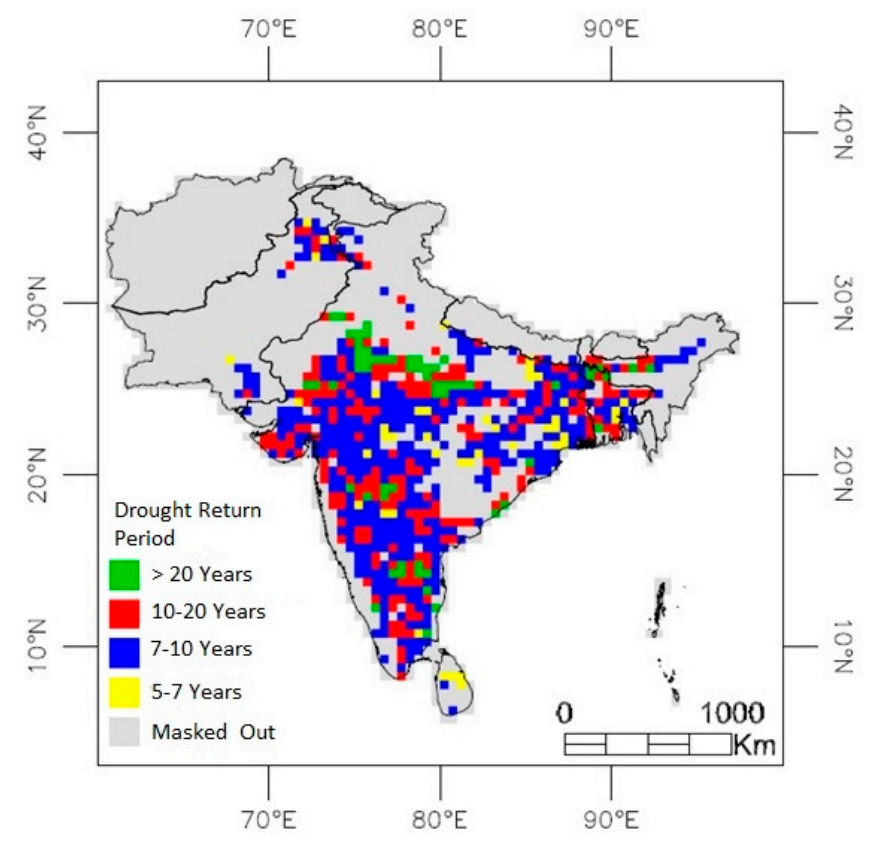

Figure 8. Grids with a five- to seven-year return period of scenario four across South Asia.

\subsection{Crop Combinations for Seed Banks}

Under scenario one, many locations require additional seeds of short duration varieties of the main crops to be maintained in seed banks. Re-sowing short duration varieties of the main crops is possible after three weeks of drought. Re-sowing of the main crops may not be possible after five weeks of drought under scenario two. Unless very short-duration varieties are available, sowing alternative crops such as millets and pulses would be the best option. Under scenario three, re-sowing of crops may not be possible after failure of the main crop due to prolonged drought of seven weeks. As the drought persists for a sufficiently long period, there is no possibility of sowing any short-duration alternative crops.

Crop combinations to store in seed banks for the use in drought period was identified only in India under the four scenarios. In many areas, short duration varieties of maize, millets, and pulses can be re-sown after the failure of the main crop. Alternative crops can be short duration varieties of pulses and groundnuts that can be easily sown after the failure of the main crop during the drought period.

Under scenario four, sowing of the main crop would not be possible due to the prolonged drought during the sowing period. Sowing of alternate short duration crops is possible with the revival of rains after the prolonged drought. In most of the areas that need additional seeds, millets (i.e., bajra, sorghum, jowar), pulses (i.e., blackgram, redgram, urad, pigeonpea), short duration maize, and soybean crops can be sown after the revival of rains. These areas need to maintain reserve seeds in seed banks for short duration varieties of the main crops and/or alternative crops.

\subsection{Economics of Seed Bank Management in Drought Prone Areas}

This study estimates the costs for maintaining additional seeds of main and alternative short duration crops in India where drought return periods are 5, 10, and 15 years. Table 2 presents a summary of cost and benefit for maintaining large seed banks in the drought prone areas. The amount of seed requirement for re-sowing after revival of rainfall increases depending on the drought return period. In many locations, the return periods of rainfall failure during main crop sowing time are 10 to 15 years or more. Therefore, the amount of additional seed requirement for re-sowing of a combination of main and alternative crops can range from 24 thousand tons (five-year return period) to 3,291 thousand tons (15-year return period). The total cost of maintaining seed banks also 
substantially increases over time. The total cost of storing seeds in the seed banks for a five-year return period accounts to US \$ 133 million. This cost will substantially increase to maintain the seeds banks for 10- and 15-year drought return periods. More than $\$ 5,000$ million US will be required to store the seeds in the seed banks for 15 years. Moreover, the average cost of seed storage (US $\$ / h a$ ) in the seed bank is significantly higher than the average per hectare cost of seeds in the study areas ranging from US \$ $50 /$ ha to US $\$ 122 /$ ha.

Table 2. Economic value of seed bank maintenance in the drought prone areas in India.

\begin{tabular}{|c|c|c|c|c|}
\hline S.N. & Particular & $\begin{array}{l}5 \text { Years Return } \\
\text { Period }\end{array}$ & $\begin{array}{c}10 \text { Years } \\
\text { Return Period }\end{array}$ & $\begin{array}{c}15 \text { Years } \\
\text { Return Period }\end{array}$ \\
\hline 1 & $\begin{array}{l}\text { Area where rainfall fails during crop sowing } \\
\text { period (in } 1000 \text { ha) }\end{array}$ & 2774 & 23,122 & 41,620 \\
\hline 2 & $\begin{array}{l}\text { Amount of seed requirement for re-sowing (in } \\
1000 \text { ton) of combination of main and alternative } \\
\text { crops }\end{array}$ & 24 & 1828 & 3291 \\
\hline 3 & Cost of seed storage in seed banks (US \$ million) & 133 & 1877 & 5,069 \\
\hline 4 & Average cost of seed storage (US $\$ /$ ha) & 50 & 81 & 122 \\
\hline 5 & $\begin{array}{l}\text { Net return from crop production in normal year } \\
\text { in the areas where rainfall fails during crop } \\
\text { sowing period (US \$ million) }\end{array}$ & 418 & 4458 & 10,242 \\
\hline 6 & $\begin{array}{l}\text { Net return from re-sowing of combination of } \\
\text { main and alternative crops after revival of } \\
\text { rainfall including crop yields losses due to late } \\
\text { sowing (US \$ million) }\end{array}$ & 209 & 2227 & 5122 \\
\hline 8 & $\begin{array}{l}\text { Total benefit from seed banks (6 minus } 3 \text { ) in US\$ } \\
\text { million }\end{array}$ & 76 & 350 & 53 \\
\hline 9 & Benefit/Cost ratio for seed bank maintenance & 1.5 & 1.2 & 1.0 \\
\hline
\end{tabular}

This estimation indicates that the cost and quantity of seeds that need to be stored in seed banks increases over time due to seed replacement requirement, storage management cost, and the discounting factor. For the maintenance of certified and foundation seeds of identified crops, fund are required for procurement of seeds, construction of seed storage facilities, processing, packaging, and transportation charges, and storage losses. We also estimate the potential benefits of maintaining seed banks in drought-prone areas under different drought return periods. The estimated net returns from crop cultivation in a normal year (on-time rainfall during crop sowing period) range from US $\$ 418$ million to 10,242 million. Drought prone areas will lose this amount of net return after complete crop failure. However, re-sowing of combination of main and alternative crops after the revival of rainfall can help in generating US \$ 209 million to 5122 million net returns depending on the drought return periods. An overall economic assessment shows that the maintenance of seed banks to store additional seeds for re-sowing in the drought prone areas is useful for short drought return periods.

\section{Conclusions}

This study systematically assessed the additional seed requirement for re-sowing of the main crop or sowing of alternative short duration crops after a failure of the main crop due to the prolonged drought condition in rainfed/partially irrigated areas of South Asia. The analysis of long-term gridded rainfall data for all South Asian countries indicates that drought during the four weeks of the crop sowing period followed by normal rainfall is a more common scenario than normal rainfall during crop sowing weeks followed by severe drought. This phenomenon of monsoon in many parts of South Asia has a serious consequence on crop sowing in optimal time to realise the production potential of many crops. Adaptation of these conditions requires multiple strategies including seed banks to be put in place. 
Despite the large areas under rainfed and partially irrigated agricultural systems in the region, only a small fraction of the areas require additional seeds of the main or alternative crops to be stored in seed banks as a way to cope with droughts once in five to seven years. For large areas in the region, additional seeds for the main or alternative crops are needed once in 10 years or more for re-sowing after the failure of the main crops due to the prolonged drought. Severe drought conditions after normal rainfall during two crop-sowing weeks is not a frequent phenomenon in the region. However, normal rainfall during the two crop-sowing weeks followed by a short period drought (about three weeks) and the revival of rainfall in subsequent weeks does exist in some places in India. Policymakers can use this information more strategically to consider setting up large seed banks in those locations as part of a plan to prepare for severe droughts.

The choice of seeds of the main crop and/or alternative crop varieties for storage in the large seed banks depends on the agro-ecological conditions and the timing and length of drought during the cropping season. In areas where prolonged drought occurs a few weeks after crop sowing, additional seeds are required to establish alternative crops on the revival of rainfall. The re-establishment of the main crops may not be possible after such a long period of drought. Re-sowing of short-duration varieties of the main crops is possible in areas where normal sowing period is followed by short duration droughts (two to three weeks). This information is also very much relevant to establish large seed banks and store the seeds of main and alternative crops in the drought prone areas. Establishment of alternative crops after severe drought and failure of the main crops can provide livelihood safety nets to the farmers by partially compensating the loss of the main crops. National and sub-national governments and the private sector can consider this method and information to identify the seed requirements for main and alternative crops in the drought-prone areas. Re-establishment of the main or alternative crops after drought-induced crop failure can have large implications for maintaining food security at local and sub-national levels. Seed banks can play a vital role in re-establishing the crops in such locations.

This study shows that, despite the large investment requirement, maintenance of large seed banks for drought-risk management is a viable option. Government or private sector can plan to invest in large seed bank for a short period of time i.e., less than a 10-year drought return period. Storing additional seeds of main or alternative crops by individual farmers for re-sowing after crop failure due to in-season droughts is not a common practice in the South Asian countries. Establishment of large seed banks in drought-prone areas can be an alternative to supply sufficient additional seeds for re-sowing of the main crops or planting of alternative crops after droughts and revival of rainfall. These seed banks can also play a crucial role in seed replacement by storing and providing quality seeds to the farmers. Periodic replacement of seeds in the seed banks by new and improved seeds can help to minimize storage management costs. National and sub-national governments, the South Asian Association for Regional Cooperation (SAARC), and other potential private sector investors in seed banks can consider this information while making decisions about establishing seed banks focusing on drought-risk management in agriculture. Large seed banks, particularly as a way to manage drought risks, can be linked with periodic seed replacement programmes, sharing of genetic resources, and biodiversity conservation.

This study presents robust scientific results that can be applied to the adaptation and mitigation of climate change in a specific sector of agriculture. Further studies can consider a detailed supply and demand side analysis of large seed banks and use of alternative sources of data for reliability and sensitivity test. In-depth country-level assessments of seed bank requirement for drought risk management can also add value to any future research. 
Supplementary Materials: The following are available online at www.mdpi.com/2071-1050/9/11/1901/s1.

Acknowledgments: We acknowledge the support for this work provided by the numerous donors contributing to the CGIAR Research Program on Climate Change, Agriculture and Food Security (CCAFS). The authors would like to thank Seema Sehgal for her contribution to the research. We also thank anonymous reviewers and editors for comments on an earlier version of the manuscript. The views expressed in the paper are those of the authors' alone.

Author Contributions: Design of the research: Pramod Aggarwal; data collection and analysis: Pramod Aggarwal, Arun Khatri-Chhetri and research consultant; drafting the article: Arun Khatri-Chhetri and Pramod Aggarwal; critical revision of the article: Arun Khatri-Chhetri and Pramod Aggarwal; Final manuscript preparation: Arun Khatri-Chhetri; and Final approval of the version to be published: Approved by Arun Khatri-Chhetri and Pramod Aggarwal.

Conflicts of Interest: The authors declare no conflict of interest. The funding organizations had no role in the design of the study, collection, analyses, and interpretation of data; in the writing of the manuscript, and in the decision to publish the results.

\section{References}

1. Lal, R. Enhancing eco-efficiency in agro-ecosystems through soil carbon sequestration. Crop Sci. 2010, 50, 120-131. [CrossRef]

2. Pandey, S.; Bhandari, H. Drought: Economic costs and research implications. In Drought Frontiers in Rice: Crop Improvement for Increased Rainfed Production; Serraj, R., Bennett, J., Hardy, B., Eds.; International Rice Research Institute (IRRI): Los Banos, Philippines; World Scientific Publishing Company: Hackensack, NJ, USA, 2009.

3. Centre for Research on the Epidemiology of Disaster. International Disaster Database: Country Profile, 2015. Available online: http:/ / www.emdat.be/ database (accessed on 15 February 2017).

4. IPCC. Summary for policymakers. In Climate Change 2014: Impacts, Adaptation, and Vulnerability; Cambridge University Press: Cambridge, UK; New York, NY, USA, 2014; pp. 1-32.

5. Parida, B.R.; Oinam, B. Unprecedented drought in North East India compared to Western India. Curr. Sci. 2015, 109, 2121-2126. [CrossRef]

6. Pathak, H.C. Drought Preparedness and Mitigation; National Academy of Agricultural Sciences (NAAS): New Delhi, India, 2011; p. 22.

7. Shahid, S. Drought risk assessment in the Western Part of Bangladesh. Available online: http://ssrn.com/ abstract $=1674437$ (accessed on 20 February 2017).

8. Sigdel, M.; Ikeda, M. Spatial and temporal analysis of drought in Nepal using standardized precipitation index and its relationship with climate indices. J. Hydrol. Meteorol. 2010, 7, 59-74. [CrossRef]

9. Ahmad, S.; Hussain, Z.; Qureshi, A.; Majeed, S.R.; Saleem, M. Drought Mitigation in Pakistan: Current Status and Options for Future Strategies; International Water Management Institute: Colombo, Sri Lanka, 2004; Available online: http:/ / www.iwmi.cgiar.org/Publications/Working_Papers/working/WOR85.pdf (accessed on 12 February 2017).

10. Annamalai, H.; Sperber, K.R. South Asian summer monsoon variability in a changing climate. In The Monsoon and Climate Change: Observation and Modeling; de Carvalho, L.M.V., Jones, C., Eds.; Springer: Cham, Switzerland, 2016.

11. Turner, A.G.; Annamalai, H. Climate change and the South Asian summer. Nat. Clim. Change 2012, 2, 587-595. [CrossRef]

12. Wilhite, D.A. Drought monitoring as a component of drought preparedness planning. In Coping with Drought Risk in Agriculture and Water Supply System; Iglesias, A., Cancelliere, A., Wilhite, D.A., Garrote, L., Cubillo, F., Eds.; Springer: Dordrecht, The Netherlands, 2009; pp. 3-19.

13. The National Disaster Management Authority. National Disaster Management Guidelines: Management of Drought; Government of India: New Delhi, India, 2010.

14. Ministry of Environment. Climate Change Policy 2011; Government of Nepal: Lalitpur, Nepal, 2011.

15. Ministry of Environment and Forest. Bangladesh Climate Change Strategy and Action Plan 2009; Government of Bangladesh: Dhaka, Bangladesh, 2009.

16. Rejani, R.; Rao, K.V.; Osman, M.; Chary, G.R.; Reddy, P.K.S.; Rao, C. Location specific insitu soil and water conservation interventions for sustainable management of drylands. J. Agrometeorol. 2015, 17, 55-60. 
17. Rockstrom, J.; Karberg, L.; Wani, S.P.; Barron, J.; Hatibu, N.; Oweis, T.; Bruggeman, A.; Farahani, J.; Qiang, Z. Managing water in rainfed agriculture: the need for paradigm shift. Agr. Water Manag. 2010, 97, 543-550. [CrossRef]

18. Singh, A. Land and water management planning for increasing farm income in irrigated dry areas. Land Use Policy 2015, 42, 244-250. [CrossRef]

19. Craufurd, P.Q.; Balaji, V. Using Information and Communication Technologies to Disseminate and Exchange Agriculture-Related Climate Information in the Indo-Gangetic Plains; CCAFS Working Paper No. 78; Agriculture and Food Security (CCAFS): Copenhagen, Denmark, 2014.

20. Wankhede, S.S.; Gandhi, N.; Armstrong, L. Role of ICTs in Improving Drought Scenario Management in India. In Proceedings of the 9th Conference of the Asian Federation for Information Technology in Agriculture, Perth, Australia, 29 September-2 October 2014.

21. SAARC. Declaration of the Seventeenth SAARC Summit. Available online: https://www.gktoday.in/ seventeenth-saarc-summit-addu-declaration/ (accessed on 10 January 2017).

22. Establishing the SAARC Regional Seed Bank. Ministry of Agriculture, Government of India. Available online: http:/ / seednet.gov.in/PDFFILES/ saarc-seedbank.pdf (accessed on 5 March 2016).

23. Adhikari, K. Seed banking in South Asia. Available online: http://www.sawtee.org/publications/ PolicyBrief-23.pdf (accessed on 15 February 2017).

24. Channan, S.; Colins, K.; Emanuel, W.R. Global mosaics of the standard MODIS land cover type data. University of Maryland and the Pacific Northwest National Laboratory: Maryland, USA, 2014. Available online: http:/ / glcf.umd.edu/data/lc/ (accessed on 6 March 2016).

25. Global Maps of Irrigation Areas (GMIA). Available online: http://www.fao.org/nr/water/aquastat/ irrigationmap/index10.stm (accessed on 6 March 2016).

26. Sivakumar, M.V.K.; Motha, R.P.; Das, H.P. Natural Disasters and Extreme Events in Agriculture: Impacts and Mitigation; Springer: Berlin, Germany, 2005.

27. Amarnath, G.; Alahacoon, N.; Smakhtin, V.; Aggarwal, P. Mapping Multiple Climate-Related Hazards in South Asia; International Water Management Institute: Colombo, Sri Lanka, 2017.

28. Mavi, H.S.; Tupper, G.J. Agrometerology: Principles and Applications of Climate Studies in Agriculture; The Haworth Press: Binghamton, NY, USA, 2004.

29. Dietz, A.J.; Put, M.; Subbiah, S. Drought risks assessment for dryland agriculture in semi-arid Telengana, Andra Pradesh, India. In The Arid Frontier; Bruins, H.J., Lithwick, H., Eds.; Springer: Dordrecht, The Netherlands, 1998.

30. Edwards, D.C.; McKee, T.B. Characteristics of 20th Century Drought in the United States at Multiple Time Scales; Colorado State University: Fort Collins, CO, USA, 1997.

31. Brouwer, C.; Heibloem, M. Irrigation Water Management: Irrigation Water Needs; Food and Agriculture Organization (FAO): Rome, Italy, 1998.

32. Udmale, P.D.; Ichikawa, Y.; Kiem, A.S.; Panda, S.N. Drought impacts and adaptation strategies for agriculture and rural livelihood in the Maharashtra State of India. Open Agric. J. 2014, 8, 14-47. [CrossRef]

33. Meter, K.J.; Basu, N.B.; Tate, E.; Wyckoff, J. Monsoon harvest: The living legacies of rainwater harvesting systems in South India. Environ. Sci. Technol. 2014, 48, 4217-4225. [CrossRef] [PubMed]

34. Fisher, H.W.; Reddy, N.L.N.; Rao, M.L.S. Can more drought resistant crops promote more climate security agriculture? Prospects and challenges of millet cultivation in Ananthapur, Andhra Pradesh. World Dev. Perspect. 2016, 2, 5-10. [CrossRef]

35. Gupta, A.K.; Tyagi, P.; Sehgal, V.K. Drought disaster challenges and mitigation in India: strategic appraisal. Curr. Sci. 2011, 100, 1796-1806.

36. Ahmed, K.; Shahid, S.; Harun, S.B.; Wang, X.J. Characterization of seasonal droughts in Balochistan Province, Pakistan. Stoch. Environ. Res. Risk Assess. 2016, 30, 747-762. [CrossRef]

37. Kumar, K.N.; Rajeevan, M.; Pai, D.S.; Srivastava, A.K.; Preethi, B. On the observed variability of monsoon droughts over India. Weather Clim. Extremes 2013, 1, 42-50. [CrossRef]

38. Greatrex, H.; Hansen, J.W.; Garvin, S.; Diro, R.; Blakeley, S.; Le, M.G.; Rao, K.N.; Osgood, D.E. Scaling up Index Insurance for Smallholder Farmers: Recent Evidence and Insights. Available online: https: / / cgspace.cgiar.org/handle/10568/53101 (accessed on 19 October 2017). 
39. Aggarwal, P.K.; Shirsath, P.B. Better Designed Weather-Based Insurance Holds Promise for Maharashtra Farmers. Available online: https://ccafs.cgiar.org/research-highlight/better-designed-weather-basedinsurance-holds-promise-maharashtra-farmers\#.WehmCFl41PY (accessed on 19 October 2017).

40. Singh, D.; Tsiang, M.; Rajaratnam, B.; Diffenbaugh, N.S. Observed changes in extreme wet and dry spells during the South Asian summer monsoon season. Nat. Clim. Change 2014, 4, 456-461. [CrossRef] 